\title{
The assessment of the diversity of weed flora communities in crops cultivated in selected farms in Lubelskie voivodeship
}

\section{Ocena różnorodności zbiorowisk segetalnych w łanach roślin uprawnych w wybranych gospodarstwach w województwie lubelskim}

\author{
Jolanta Bojarszczuk ${ }^{1 *}$, Janusz Podleśny ${ }^{1}$, Jarosław Nowak ${ }^{2}$
}

\section{Summary}

The aim of the study was to evaluate the weed infestation in selected crops cultivated in farms in Lubelskie voivodeship in correlation to size of agricultural land. The analysis showed that the species composition of weed communities in the field of cultivated plants differed depending on the size of the farm and the crop. The fields of winter wheat were infested the most, while winter rape fields were the least. The most weeds in crops of winter rape were found in the largest farms (above 100 ha of agricultural land), respectively for wheat and rape: 108 and $88 \mathrm{pcs} / \mathrm{m}^{2}$, while the least undesirable species were found in farms up to 20 ha of arable land, respectively: 33 and 20 items $/ \mathrm{m}^{2}$. The evaluation of diversity of segetal flora using the Shannon-Wiener diversity index and Simpson domination did not show significant differences between particular groups of farms. Due to the fact that the weed populations were dominated by several species, relatively small values of Shannon-Wiener indexes and large Simpson domains were obtained. The most numerous species of weeds, regardless of the type of crop, were: Chenopodium album, Viola arvensis, Echinochloa crus-galli, Anthemis arvensis, Apera spica-venti, Stellaria media.

Key words: farms; dominance index; diversity; weed communities

\section{Streszczenie}

Celem przeprowadzonych badań była ocena zachwaszczenia w uprawie wybranych gatunków roślin w gospodarstwach zróżnicowanych powierzchnią użytków rolnych położonych w województwie lubelskim. Przeprowadzona analiza wykazała, że skład gatunkowy zbiorowisk chwastów w łanie uprawianych roślin różnił się w zależności od wielkości gospodarstwa oraz rośliny uprawnej. Najbardziej zachwaszczone były łany pszenicy ozimej, natomiast najmniej rzepaku ozimego. Najwięcej chwastów w łanach roślin uprawnych form ozimych stwierdzono w gospodarstwach największych obszarowo (powyżej 100 ha UR), odpowiednio dla pszenicy i rzepaku: 108 i 88 szt./m², natomiast najmniej gatunków niepożądanych stwierdzono w gospodarstwach do 20 ha użytków rolnych, odpowiednio: 33 i 20 szt./m². Ocena różnorodności biologicznej flory segetalnej za pomocą wskaźników różnorodności Shannona-Wienera i dominacji Simpsona nie wykazała znacznych różnic pomiędzy poszczególnymi grupami gospodarstw. Ze względu na to, że populacje chwastów były zdominowane przez kilka gatunków uzyskano stosunkowo małe wartości wskaźników Shannona-Wienera i duże wskaźników dominacji Simpsona. Najliczniej występującymi gatunkami chwastów niezależnie od gatunku rośliny uprawnej były: Chenopodium album, Viola arvensis, Echinochloa crus-galli, Anthemis arvensis, Apera spica-venti, Stellaria media.

Słowa kluczowe: gospodarstwa; indeks dominacji; różnorodność; zbiorowiska chwastów

\footnotetext{
${ }^{1}$ Instytut Uprawy Nawożenia i Gleboznawstwa - Państwowy Instytut Badawczy

Czartoryskich 8, 24-100 Puławy

${ }^{2}$ Świętokrzyski Ośrodek Doradztwa Rolniczego w Modliszewicach

Modliszewice, Piotrkowska 30, 26-200 Końskie

*corresponding author: jbojarszczuk@iung.pulawy.pl
} 


\section{Wstęp / Introduction}

Chwasty stanowią roślinność niepożądaną w łanach roślin uprawnych. Ich występowanie w dużej liczebności prowadzi do obniżki wielkości i jakości plonu, a w konsekwencji zmniejszenia opłacalności produkcji roślinnej. Szkodliwość chwastów polega także na rozprzestrzenianiu patogenów, bowiem niektóre gatunki mogą być żywicielami dla różnych grup chorób i szkodników (Gołębiowska 2007). Obecność chwastów w łanie utrudnia zbiór roślin uprawnych poprzez zapychanie zespołów roboczych maszyn żniwnych lub nadmierne wyleganie łanu. W nowoczesnym rolnictwie ze względów ekonomicznych i przyrodniczych bardzo często rezygnuje się z całkowitego zwalczania tych gatunków chwastów, których liczebność nie przekracza progu ekonomicznej szkodliwości (Rola i Rola 2002). Chwasty powodują zwykle większe straty w plonie roślin niż choroby i szkodniki, dlatego stanowią duże zagrożenie we wszystkich systemach rolniczych. Ograniczanie zachwaszczenia związane jest z ponoszeniem przez rolnika znacznych kosztów, co wpływa bezpośrednio na opłacalność stosowanej technologii produkcji roślinnej. Decyzja o zakresie stosowania walki z chwastami zależy od możliwości ekonomicznych gospodarstwa, które w znacznym stopniu uwarunkowane są jego powierzchnią (Ziętara i Zieliński 2016). Ponadto nasilenie występowania chwastów łanie różnych gatunków roślin uprawnych jest inne i wymaga często stosowania odmiennych metod ich zwalczania(Rola 2002). Można zatem przypuszczać, że występuje duże zróżnicowanie w zachwaszczeniu, w zależności od gatunku rośliny uprawnej oraz wielkości gospodarstwa.

Celem przeprowadzonych badań była ocena zachwaszczenia w uprawie wybranych gatunków roślin w gospodarstwach w województwie lubelskim, zróżnicowanych powierzchnią użytków rolnych.

\section{Materiały i metody / Materials and methods}

Materiał źródłowy stanowiły wyniki badań ankietowych przeprowadzonych w 2016 roku w 25 wybranych gospodarstwach zlokalizowanych w województwie lubelskim. Do celów analitycznych dokonano podziału gospodarstw na 5 grup różniących się powierzchnią użytków rolnych (UR): I - do 20 ha, II - od 21 do 30, III - od 31 do 50, IV - od 51 do 100 i V - powyżej 100 ha. Ocenę zachwaszczenia przeprowadzono przed zbiorem roślin. Najczęściej stosowanymi środkami ochrony roślin w badanych gospodarstwach były: Lancet Plus 125 WG, Sekator 125 OD, Maraton 375 SC, Command 480 EC, Metazanex 500 SC, Lintur 75 WG, Puma Universal 069 EW, Chwastox Turbo 340 SL, Chwastox Trio 540 SL.

W ocenie zachwaszczenia uwzględnione zostały 3 gatunki roślin, form jarych i ozimych (pszenica ozima, jęcz- mień jary, rzepak ozimy). Badania obejmowały ocenę składu gatunkowego chwastów oraz liczebności poszczególnych gatunków.

Strukturę zbiorowisk chwastów w badanych uprawach opisano także za pomocą dwóch wskaźników ekologicznych: indeksu różnorodności Shannona (H') oraz indeksu dominacji Simpsona (SI). Indeks Shanonna jest wskaźnikiem ogólnej różnorodności gatunkowej. Jego wartość określa prawdopodobieństwo, że dwa wylosowane z próbki osobniki będą należały do różnych gatunków. Uzależniony jest od liczby gatunków oraz ich wzajemnych proporcji ilościowych i obliczany według wzoru Shannona i Weavera (Zanin i wsp. 1992):

$$
\mathrm{H}^{\prime}=-\sum \mathrm{Pi} \ln \mathrm{Pi}
$$

gdzie: Pi - stosunek liczby chwastów danego gatunku do ogólnej liczebności chwastów na powierzchni próbnej.

Indeks Simpsona (SI) jest wskaźnikiem stosowanym do oszacowania różnorodności biologicznej siedlisk. Określa prawdopodobieństwo wylosowania dwóch osobników należących do tego samego gatunku. Uwzględnia liczbę gatunków oraz względną liczebność każdego gatunku i opisany jest wzorem Simpsona (Zanin i wsp. 1992):

$$
\mathrm{SI}=\sum \mathrm{Pi}^{2}
$$

\section{Wyniki i dyskusja / Results and discussion}

W badanych gospodarstwach stwierdzono ogółem od 7 do 9 gatunków roślin towarzyszących uprawom. Skład gatunkowy zbiorowisk chwastów różnił się w zależności od wielkości gospodarstwa oraz gatunku rośliny uprawnej. Najwięcej gatunków chwastów rozpoznano w łanie pszenicy ozimej uprawianej w gospodarstwach o powierzchni w zakresie 21-30 ha (tab. 1), w łanie rzepaku ozimego w gospodarstwach o powierzchni powyżej 100 ha (tab. 2) oraz $\mathrm{w}$ uprawie jęczmienia jarego $\mathrm{w}$ gospodarstwach o powierzchni 31-50 ha (11 gatunków) (tab. 3).

Niezależnie od rodzaju uprawy, bardziej liczne były gatunki dwuliścienne, które stanowiły w ogólnej liczebności chwastów średnio od $68,5 \% \mathrm{w}$ uprawie pszenicy ozimej do $77 \%$ w uprawie jęczmienia jarego. Udział ich był zróżnicowany w zależności od wielkości gospodarstwa wyrażonej powierzchnią użytków rolnych. W uprawie pszenicy ozimej w gospodarstwach o powierzchni powyżej 100 ha użytków rolnych udział chwastów dwuliściennych był niższy od średniej dla wszystkich gospodarstw i wyniósł 57,4\%, co wynikało $\mathrm{z}$ dużego udziału chwastów jednoliściennych (miotły zbożowej) (rys. 1, tab. 4). W łanie rzepaku ozimego w gospodarstwach najmniejszych obszarowo stwierdzono udział chwastów dwuliściennych o $28 \%$ niższy niż średnio dla wszystkich gospodarstw (rys. 2, tab. 5). Natomiast w łanie jęczmienia jarego w największych 
Tabela 1. Liczba gatunków chwastów [szt. $\left./ \mathrm{m}^{2}\right]$ w uprawie pszenicy ozimej

Table 1. Number of weed species [number $\left./ \mathrm{m}^{2}\right]$ in winter wheat

\begin{tabular}{l|c|c|c|c|c|c}
\hline \multirow{2}{*}{\multicolumn{1}{c}{ Wyszczególnienie - Specification }} & \multicolumn{5}{c|}{ Grupa obszarowa gospodarstw } & \multicolumn{2}{c}{$\begin{array}{c}\text { Średnio } \\
\text { Mean }\end{array}$} \\
\cline { 2 - 6 } & \multicolumn{1}{c|}{ I } & II & III & IV & V & \\
\hline Chwasty jednoliścienne - Monocotyledonous & 10 & 18 & 16 & 23 & 46 & 23 \\
Chwasty dwuliścienne - Dicotyledonous & 23 & 53 & 42 & 50 & 62 & 46 \\
Liczba gatunków - Number of species & 9 & 11 & 8 & 8 & 6 & 9 \\
\hline
\end{tabular}

Liczba gatunków - Number of species

Udział chwastów w ogólnej liczbie chwastów - Share of weeds in total number of weeds [\%]

Chwasty jednoliścienne - Monocotyledonous

Chwasty dwuliścienne - Dicotyledonous

\begin{tabular}{l|l|l|l|l|l}
30,3 & 25,4 & 27,6 & 31,5 & 42,6 & 31,5
\end{tabular}

\begin{tabular}{l|l|l|l|l}
69,7 & 74,6 & 72,4 & 68,5 & 57,4 \\
\hline
\end{tabular}

68,5

Źródło: opracowanie własne - Source: own elaboration

Tabela 2. Liczba gatunków chwastów [szt. $\left./ \mathrm{m}^{2}\right]$ w uprawie rzepaku ozimego

Table 2. Number of weed species [number $\left./ \mathrm{m}^{2}\right]$ in winter rape

\begin{tabular}{|c|c|c|c|c|c|c|}
\hline \multirow{2}{*}{ Wyszczególnienie - Specification } & \multicolumn{5}{|c|}{$\begin{array}{l}\text { Grupa obszarowa gospodarstw } \\
\text { Group of area farm }\end{array}$} & \multirow{2}{*}{$\begin{array}{l}\text { Średnio } \\
\text { Mean }\end{array}$} \\
\hline & I & II & III & IV & $\mathrm{V}$ & \\
\hline Chwasty jednoliścienne - Monocotyledonous & 11 & 13 & 2 & 22 & 26 & 15 \\
\hline Chwasty dwuliścienne - Dicotyledonous & 9 & 73 & 36 & 46 & 62 & 45 \\
\hline Liczba gatunków - Number of species & 4 & 9 & 10 & 7 & 11 & 8 \\
\hline \multicolumn{7}{|c|}{ Udział chwastów w ogólnej liczbie chwastów - Share of weeds in total number of weeds [\%] } \\
\hline Chwasty jednoliścienne - Monocotyledonous & 55,0 & 15,1 & 5,3 & 32,4 & 29,6 & 27,5 \\
\hline Chwasty dwuliścienne - Dicotyledonous & 45,0 & 84,9 & 94,7 & 67,6 & 70,4 & 72,5 \\
\hline
\end{tabular}

Źródło: opracowanie własne - Source: own elaboration

Tabela 3. Liczba gatunków chwastów [szt. $\left./ \mathrm{m}^{2}\right]$ w uprawie jęczmienia jarego

Table 3. Number of weed species [number $\left./ \mathrm{m}^{2}\right]$ in spring barley

\begin{tabular}{|c|c|c|c|c|c|c|}
\hline \multirow[t]{2}{*}{ Wyszczególnienie - Specification } & \multicolumn{5}{|c|}{$\begin{array}{c}\text { Grupa obszarowa gospodarstw } \\
\text { Group of area farm }\end{array}$} & \multirow{2}{*}{$\begin{array}{c}\text { Średnio } \\
\text { Mean }\end{array}$} \\
\hline & I & II & III & IV & $\mathrm{V}$ & \\
\hline Chwasty jednoliścienne - Monocotyledonous & 4 & 15 & 10 & 8 & 37 & 15 \\
\hline Chwasty dwuliścienne - Dicotyledonous & 36 & 86 & 55 & 52 & 23 & 50 \\
\hline Liczba gatunków - Number of species & 6 & 7 & 10 & 9 & 5 & 7 \\
\hline \multicolumn{7}{|c|}{ Udział chwastów w ogólnej liczbie chwastów - Share of weeds in total number of weeds [\%] } \\
\hline Chwasty jednoliścienne - Monocotyledonous & 10,0 & 14,9 & 15,4 & 13,3 & 61,7 & 23,0 \\
\hline Chwasty dwuliścienne - Dicotyledonous & 90,0 & 85,1 & 84,6 & 86,7 & 38,3 & 77,0 \\
\hline
\end{tabular}

Źródło: opracowanie własne - Source: own elaboration

gospodarstwach (o powierzchni powyżej 100 ha) zanotowano duży udział chwastów jednoliściennych, w tym przede wszystkim miotły zbożowej i owsa głuchego (rys. 3, tab. 6).

Skład gatunkowy zbiorowisk chwastów różnił się w zależności od wielkości gospodarstwa oraz rośliny uprawnej. Najbardziej zachwaszczona była uprawa pszenicy ozimej, w której stwierdzono średnio 69 sztuk gatunków chwastów (tab. 4), najmniej zaś uprawa rzepaku ozimego, gdzie zanotowano 60 sztuk gatunków niepożądanych na powierzchni $1 \mathrm{~m}^{2}$ (tab. 5). Natomiast w łanie jęczmienia jarego stwierdzono średnio 65 sztuk taksonów chwastów na jednostce powierzchni (tab. 6).

Najwięcej taksonów chwastów w łanach roślin uprawnych form ozimych na jednostce powierzchni stwierdzono w gospodarstwach powyżej 100 ha UR, odpowiednio dla pszenicy i rzepaku: 108 i 88 szt. $/ \mathrm{m}^{2}$, natomiast najmniej w gospodarstwach do 20 ha użytków rolnych, odpowiednio: 33 i 20 szt. $/ \mathrm{m}^{2}$ oraz 40 sztuk w łanie jęczmienia jarego.

Podobne wyniki uzyskała w swoich badaniach FeledynSzewczyk (2012), która wykazała, że jednym z gatunków 


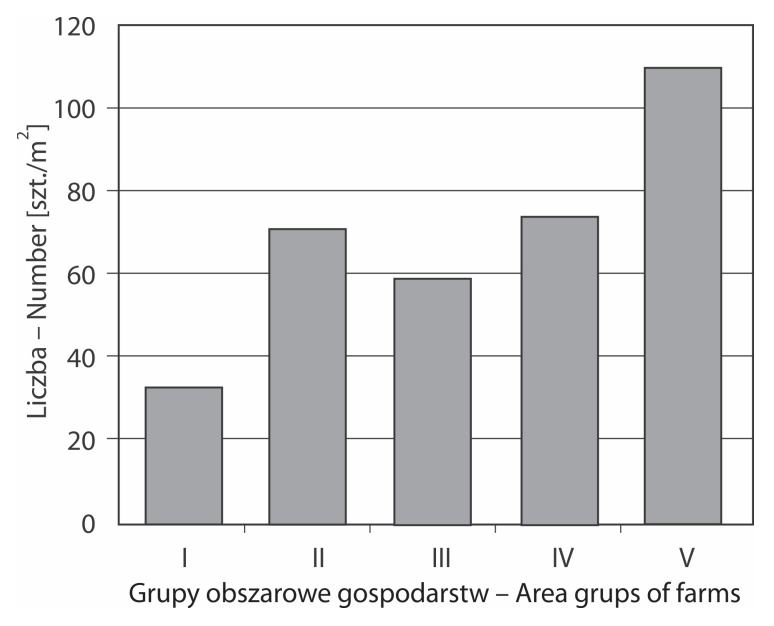

Rys. 1. Liczebność chwastów ogółem w łanie pszenicy ozimej Fig. 1. Number of total weeds in winter wheat zbóż ozimych charakteryzującym się największym zachwaszczeniem była pszenica, w której zanotowano średnio 82 gatunki chwastów na $1 \mathrm{~m}^{2}$ powierzchni.

Według Stupnickiej-Rodzynkiewicz i wsp. (2004) skład gatunkowy zachwaszczenia wywiera wpływ na szkodliwość zbiorowiska chwastów, bowiem poszczególne gatunki różnią się zdolnościami konkurencyjnymi w stosunku do rośliny uprawnej. Autorzy ci uważają, że im większa różnorodność składu gatunkowego zbiorowiska tym mniejsza jest jego szkodliwość.

Chwasty towarzyszące roślinom uprawnym odznaczają się wielostronną szkodliwością działania i w znacznym stopniu decydują o uzyskiwanych plonach (Woźnica 2008). Skala presji chwastów zależy od gatunku, odmiany, formy biologicznej roślin oraz ich naturalnej konkurencyjności nadziemnej i korzeniowej wobec chwastów (Adamiak 2007).

Tabela 4. Skład gatunkowy i liczebność chwastów w łanie pszenicy ozimej w gospodarstwach zróżnicowanych powierzchnią użytków rolnych $\left[\mathrm{szt} . / \mathrm{m}^{2}\right]$

Table 4. Weed species composition and number of weeds in winter wheat in farms of various agricultural land $\left[\mathrm{number} / \mathrm{m}^{2}\right]$

\begin{tabular}{|c|c|c|c|c|c|c|}
\hline \multirow[t]{2}{*}{ Gatunek chwastu - Weed species } & \multicolumn{5}{|c|}{$\begin{array}{c}\text { Grupa obszarowa gospodarstw } \\
\text { Group of area farm }\end{array}$} & \multirow{2}{*}{$\begin{array}{c}\text { Średnio } \\
\text { Mean }\end{array}$} \\
\hline & I & II & III & IV & $\mathrm{V}$ & \\
\hline \multicolumn{7}{|c|}{ Chwasty jednoliścienne - Monocotyledonous } \\
\hline Chwastnica jednostronna - Echinochloa crus-galli & 5 & - & - & 10 & - & 3,0 \\
\hline Miotła zbożowa - Apera spica-venti & - & 15 & 16 & 13 & 46 & 18,0 \\
\hline Owies głuchy - Avena fatua & 4 & 3 & - & - & - & 1,4 \\
\hline Perz właściwy - Elymus repens & 1 & - & - & - & - & 0,2 \\
\hline $\begin{array}{l}\text { Suma chwastów jednoliściennych } \\
\text { Sum of monocotyledonous }\end{array}$ & 10 & 18 & 16 & 23 & 46 & 23,0 \\
\hline
\end{tabular}

Sum of monocotyledonous

Chwasty dwuliścienne - Dicotyledonous

Bodziszek porozcinany - Geranium dis
Bylica pospolita - Artemisia vulgaris
Chaber bławatek - Centaurea cyanus
Fiołek polny - Viola arvensis
Gwiazdnica pospolita - Stellaria media

Komosa biała - Chenopodium album

Mak polny - Papaver rhoeas

Maruna bezwonna - Matricaria maritima subsp. inodora

Ostrożeń polny - Cirsium arvense

Poziewnik szorstki - Galeopsis tetrahit

Przetacznik perski - Veronica persica

Przytulia czepna - Galium aparine

Rdest powojowy - Fallopia convolvulus

Rumian polny - Anthemis arvensis

Szarłat szorstki - Amaranthus retroflexus

Żółtlica drobnokwiatowa - Galinsoga parviflora

Suma chwastów dwuliściennych

Sum of dicotyledonous

\begin{tabular}{c|c|c|c}
- & - & - & - \\
2 & - & - & - \\
- & 9 & 8 & 7 \\
7 & 10 & 9 & 8 \\
- & - & - & 12 \\
5 & 3 & 1 & - \\
- & 4 & - & - \\
- & 4 & - & - \\
- & 10 & - & - \\
- & - & - & - \\
- & - & 7 & - \\
1 & 7 & 9 & 5 \\
5 & 1 & - & - \\
- & 5 & 5 & 8 \\
- & - & - & 10 \\
3 & - & 3 & - \\
23 & 53 & 42 & 50 \\
33 & 71 & 58 & 73
\end{tabular}

\begin{tabular}{c|c|c}
- & 8 & 1,6 \\
- & - & 0,4 \\
7 & 11 & 7,0 \\
8 & 20 & 10,8 \\
12 & - & 2,4 \\
- & - & 1,8 \\
- & - & 0,8 \\
- & - & 0,8 \\
- & - & 2,0 \\
- & 8 & 1,6 \\
- & - & 1,4 \\
5 & 15 & 7,4 \\
- & - & 1,2 \\
8 & - & 3,6 \\
10 & - & 2,0 \\
- & - & 1,2 \\
50 & 62 & 46,0 \\
73 & 108 & 69,0 \\
\hline
\end{tabular}

Źródło: opracowanie własne - Source: own elaboration 


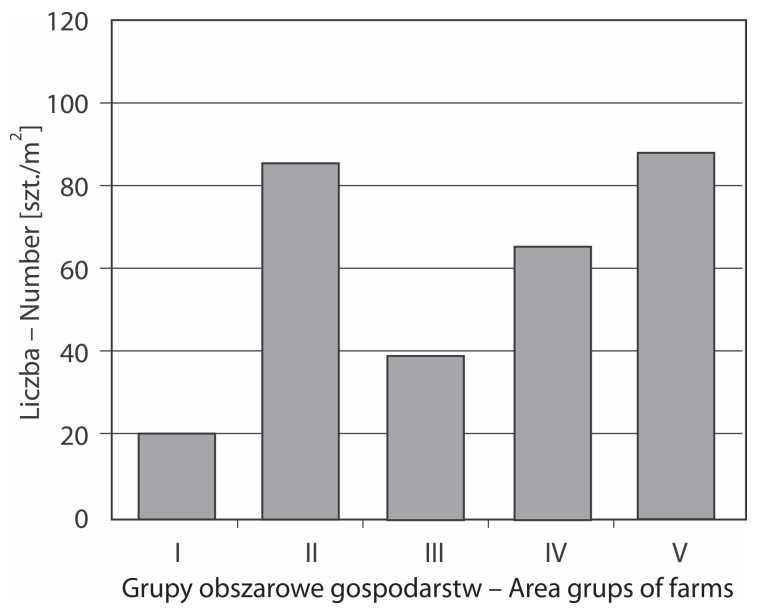

Rys. 2. Liczebność chwastów ogółem w łanie rzepaku ozimego Fig. 2. Number of total weeds in winter rape
Zdaniem Kwiatkowskiego (2009) intensywna pielęgnacja pozwala na ograniczenie występowania chwastów w łanie do 7-10 gatunków. Analizując skład florystyczny stwierdzono, że w uprawie pszenicy ozimej najliczniej występowały następujące taksony chwastów dwuliściennych: Viola arvensis, Galium aparine oraz chwastów jednoliściennych: Apera spica-venti, która stanowiła $26 \%$ populacji wszystkich występujących chwastów. Natomiast w łanie rzepaku ozimego dominowały: Stellaria media, V. arvensis, Thlaspi arvense oraz Echinochloa crus-galli jako przedstawiciel chwastów jednoliściennych. W uprawie jęczmienia jarego najliczniej występującymi gatunkami niepożądanymi niezależnie od wielkości gospodarstwa były: Anthemis arvensis, Centaurea cyanus, V. arvensis, Chenopodium album, Galium aparine oraz jeden gatunek spośród chwastów jednoliściennych: A. spica-venti. W badaniach

Tabela 5. Różnorodność gatunkowa i liczebność chwastów w łanie rzepaku ozimego w gospodarstwach zróżnicowanych powierzchnią użytków rolnych $\left[\mathrm{szt} . / \mathrm{m}^{2}\right]$

Table 5. Weed species composition and number of weeds in winter rape in farms of various agricultural land [number $\left./ \mathrm{m}^{2}\right]$

\begin{tabular}{|c|c|c|c|c|c|c|}
\hline \multirow[t]{2}{*}{ Gatunek - Weed species } & \multicolumn{5}{|c|}{$\begin{array}{c}\text { Grupa obszarowa gospodarstw } \\
\text { Group of area farm }\end{array}$} & \multirow{2}{*}{$\begin{array}{l}\text { Średnio } \\
\text { Mean }\end{array}$} \\
\hline & I & II & III & IV & $\mathrm{V}$ & \\
\hline \multicolumn{7}{|c|}{ Chwasty jednoliścienne - Monocotyledonous } \\
\hline Chwastnica jednostronna - Echinochloa crus-galli & 6 & 13 & - & - & 26 & 9,0 \\
\hline Miotła zbożowa - Apera spica-venti & - & - & 1 & 12 & - & 2,6 \\
\hline Perz właściwy - Elymus repens & 5 & - & 1 & 10 & - & 3,2 \\
\hline $\begin{array}{l}\text { Suma chwastów jednoliściennych } \\
\text { Sum of monocotyledonous }\end{array}$ & 11 & 13 & 2 & 22 & 26 & 14,8 \\
\hline \multicolumn{7}{|c|}{ Chwasty dwuliścienne - Dicotyledonous } \\
\hline Chaber bławatek - Centaurea cyanus & - & 5 & 5 & 6 & 1 & 3,4 \\
\hline Fiołek polny - Viola arvensis & 4 & 25 & 8 & 5 & - & 8,4 \\
\hline Gwiazdnica pospolita - Stellaria media & - & - & 10 & 20 & 20 & 10,0 \\
\hline Jasnota różowa - Lamium amplexicaule & - & - & - & - & 1 & 0,2 \\
\hline Komosa biała-Chenopodium album & 5 & 10 & 3 & - & - & 3,6 \\
\hline Mak polny - Papaver rhoeas & - & - & - & 8 & 3 & 2,2 \\
\hline Maruna bezwonna - Matricaria maritima subsp. inodora & - & - & 1 & - & - & 0,2 \\
\hline Ostrożeń polny - Cirsium arvense & - & 5 & - & - & 2 & 1,4 \\
\hline Poziewnik szorstki - Galeopsis tetrahit & - & - & - & - & 2 & 0,4 \\
\hline Przetacznik perski - Veronica persica & - & - & 4 & - & - & 0,8 \\
\hline Przytulia czepna - Galium aparine & - & - & 1 & - & 12 & 2,6 \\
\hline Rdest plamisty - Polygonum persicaria & - & - & - & - & 2 & 0,4 \\
\hline Rumian polny - Anthemis arvensis & - & 1 & - & 7 & - & 1,6 \\
\hline Szarłat szorstki - Amaranthus retroflexus & - & 1 & - & - & - & 0,2 \\
\hline Tasznik pospolity - Capsella bursa-pastoris & - & 2 & 4 & - & 2 & 1,6 \\
\hline Tobołki polne - Thlaspi arvense & - & 24 & - & - & 17 & 8,2 \\
\hline $\begin{array}{l}\text { Suma chwastów dwuliściennych } \\
\text { Sum of dicotyledonous }\end{array}$ & 9 & 73 & 36 & 46 & 62 & 45,2 \\
\hline Razem - Total & 20 & 86 & 38 & 68 & 88 & 60,0 \\
\hline
\end{tabular}

Źródło: opracowanie własne - Source: own elaboration 


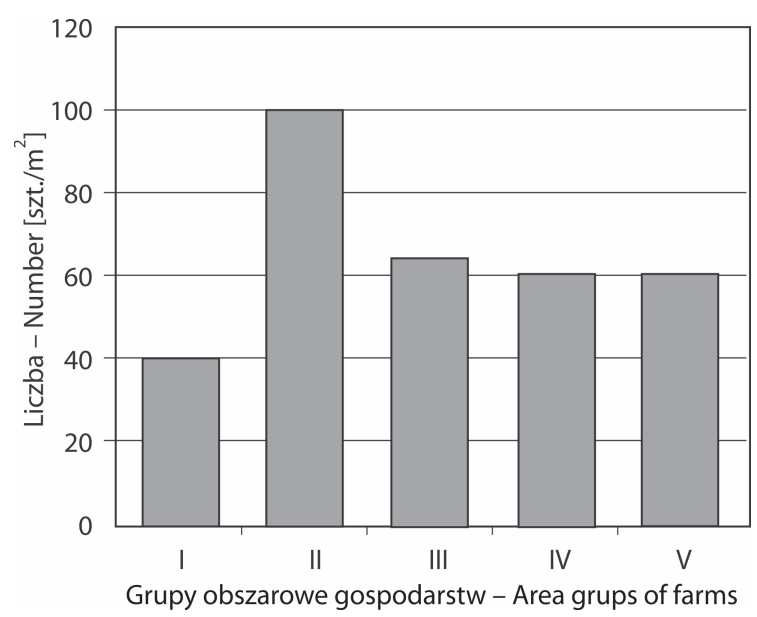

Rys. 3. Liczebność chwastów ogółem w łanie jęczmienia jarego Fig. 3. Number of total weeds in spring barley

Orzecha i wsp. (2011) w zasiewach jęczmienia jarego uprawianego w systemie tradycyjnym szczególnie licznie występowało 5 taksonów chwastów: Capsella bursa-pastoris, Cirsium arvense, S. media, V. arvensis oraz Ch. album.
Ocena różnorodności biologicznej flory segetalnej za pomocą wskaźników różnorodności Shannona-Wienera i dominacji Simpsona nie wykazała znacznych różnic pomiędzy poszczególnymi grupami gospodarstw (tab. 4, 5, 6). W uprawie pszenicy ozimej jedynie gospodarstwo o największej powierzchni odbiegało od pozostałych, charakteryzując się stosunkowo niską wartością indeksu Shannona-Wienera i wysoką wartością indeksu Simpsona, co wskazuje na wyraźną dominację w zbiorowisku jednego lub dwóch gatunków chwastów (A. spica-venti i $V$. arvensis). Gospodarstwo to jednocześnie charakteryzowało się najmniejszą liczbą oznaczonych gatunków chwastów (6 taksonów), ale jednocześnie najbogatszym składem gatunkowym flory segetalnej (108 gatunków).

Spośród badanych gatunków roślin uprawnych największą różnorodnością, ocenianą za pomocą wskaźnika Shannona, charakteryzowało się zbiorowisko chwastów w uprawie pszenicy ozimej w gospodarstwie o powierzchni w zakresie 21-30 ha (II grupa). Najwyższe wartości indeksu dominacji $(\mathrm{Si}>0,60)$ stwierdzono dla jęczmienia jarego uprawianego w gospodarstwach o najmniejszej powierzchni (I grupa), co świadczy o dominacji pewnych gatunków chwastów ( $V$. arvensis i S.media) (tab. 6).

Tabela 6. Różnorodność gatunkowa i liczebność chwastów w łanie jęczmienia jarego w gospodarstwach zróżnicowanych powierzchnią użytków rolnych $\left[\mathrm{szt} . / \mathrm{m}^{2}\right]$

Table 6. Weed species composition and number of weeds in spring barley in farms of various agricultural land $\left[\mathrm{number} / \mathrm{m}^{2}\right]$

\begin{tabular}{|c|c|c|c|c|c|c|}
\hline \multirow[t]{2}{*}{ Gatunek - Weed species } & \multicolumn{5}{|c|}{$\begin{array}{c}\text { Grupa obszarowa gospodarstw } \\
\text { Group of area farm }\end{array}$} & \multirow{2}{*}{$\begin{array}{l}\text { Średnio } \\
\text { Mean }\end{array}$} \\
\hline & I & II & III & IV & $\mathrm{V}$ & \\
\hline \multicolumn{7}{|c|}{ Chwasty jednoliścienne - Monocotyledonous } \\
\hline Chwastnica jednostronna - Echinochloa crus-galli & - & - & - & 8 & - & 1,6 \\
\hline Miotła zbożowa - Apera spica-venti & - & 15 & - & - & 20 & 7,0 \\
\hline Owies głuchy - Avena fatua & 4 & - & 10 & - & 17 & 4,2 \\
\hline $\begin{array}{l}\text { Suma chwastów jednoliściennych } \\
\text { Sum of monocotyledonous }\end{array}$ & 4 & 15 & 10 & 8 & 37 & 15,0 \\
\hline \multicolumn{7}{|c|}{ Chwasty dwuliścienne - Dicotyledonous } \\
\hline Chaber bławatek-Centaurea cyanus & 0 & 15 & 15 & - & 5 & 8,0 \\
\hline Fiołek polny - Viola arvensis & 18 & 2 & 13 & 4 & - & 7,4 \\
\hline Gwiazdnica pospolita - Stellaria media & 10 & - & 2 & - & - & 2,4 \\
\hline Komosa biała-Chenopodium album & - & 10 & 5 & 10 & 10 & 7,0 \\
\hline Maruna bezwonna - Matricaria maritima subsp. inodora & - & - & 2 & 10 & - & 2,4 \\
\hline Ostrożeń polny - Cirsium arvense & - & 4 & 1 & - & - & 1,0 \\
\hline Przytulia czepna - Galium aparine & 4 & 15 & 5 & 2 & 8 & 6,8 \\
\hline Rdest powojowy - Fallopia convolvulus & - & - & - & 3 & - & 0,6 \\
\hline Rumian polny - Anthemis arvensis & 4 & 40 & 2 & 8 & - & 10,8 \\
\hline Tasznik pospolity - Capsella bursa-pastoris & - & - & 10 & 10 & - & 4,0 \\
\hline Tobołki polne - Thlaspi arvense & - & - & - & 5 & - & 1,0 \\
\hline $\begin{array}{l}\text { Suma chwastów dwuliściennych } \\
\text { Sum of dicotyledonous }\end{array}$ & 36 & 86 & 55 & 52 & 23 & 50,4 \\
\hline Razem - Total & 40 & 101 & 65 & 60 & 60 & 65,2 \\
\hline
\end{tabular}


Zbliżone wartości wskaźników zbiorowisk chwastów są wynikiem stosunkowo dużej różnorodności gatunkowej we wszystkich grupach gospodarstw.

Z badań Feledyn-Szewczyk i Duer (2007) oraz Janczak-Tabaszewskiej i Tyburskiego (1999) wynika, że przy stosowaniu właściwej agrotechniki we wszystkich roślinach wchodzących w skład płodozmianu możliwe jest utrzymanie chwastów na poziomie niepowodującym istotnego spadku plonu.

Analiza badań przeprowadzonych przez Kapelusznego i Haliniarz (2010) na podstawie 360 zdjęć fitosocjologicznych wykonanych metodą BraunBlanquet'a wykazała, że Descurainia sophia, Lactuca serriola i Artemisia vulgaris są dość częstym elementem zachwaszczenia roślin uprawnych na terenie województwa lubelskiego. Omawiane gatunki zasiedlały przede wszystkim ozime formy zbóż i rzepaku. W badaniach tych autorów, ponad 50\% wszystkich stanowisk $A$. vulgaris i L. serriola oraz $42 \%$ D. sophia występowało w zbożach ozimych. Nieznacznie mniej stanowisk ocenianych chwastów zlokalizowano w rzepaku ozimym, co wynika ze znacznie mniejszego areału uprawy rzepaku niż roślin zbożowych na Lubelszczyźnie.

$\mathrm{Na}$ podstawie przeprowadzonej analizy dotyczącej sposobu regulacji zachwaszczenia prowadzonych upraw wynika, że w gospodarstwach mniejszych (do 20 ha) decyzję o wykonaniu zabiegu podejmowano głównie w oparciu o własne obserwacje (tab. 7), wybierając najczęściej preparat na podstawie aktualnej jego ceny (90\%). Natomiast w gospodarstwach o większej powierzchni (powyżej 51 ha) głównym wyznacznikiem decydującym o wyborze pestycydu była jego skuteczność działania, bowiem średnio 63\% kierowało się tym warunkiem. Ponadto w 10\% tych gospodarstw decyzja o wykonaniu zabiegu podejmowana była w oparciu o próg ekonomicznej szkodliwości, a więc w sytuacji, gdzie nasilenie agrofaga było na tyle duże, że wykonanie zabiegu było opłacalne ze względu na możliwe straty wynikające $\mathrm{z}$ obniżenia plonu. Właściciele większych obszarowo gospodarstw decyzję o wykonaniu zabiegu podejmowali w oparciu o profesjonalne doradztwo służb doradczych. Potwierdza to fakt, że potencjał ekonomiczny gospodarstwa w dużym stopniu decyduje o sposobie i zakresie prowadzonej ochrony chemicznej.

Skuteczność przeprowadzonych zabiegów ochrony roślin $\mathrm{w}$ badanych gospodarstwach określono jako bardzo wysoką, bowiem przekraczającą 90\% niezależnie od powierzchni użytków rolnych (tab. 7). Skuteczność chwastobójcza środka chemicznego zależy od rodzaju zawartej w nim substancji czynnej, stopnia zachwaszczenia pola i fazy rozwojowej chwastów, a także kondycji rośliny uprawnej (Domaradzki i wsp. 2003; Wesołowski i wsp. 2005). Stąd tak duże znaczenie ma wybór rodzaju środka i terminu wykonania zabiegu. Można zatem uznać, że zabiegi chemiczne stosowane w celu ograniczenia zachwaszczenia analizowanych gatunków roślin uprawnych były wykonywane $\mathrm{w}$ analizowanych gospodarstwach w miarę poprawnie, z zachowaniem najważniejszych zasad ochrony chemicznej i warunkach pogodowych sprzyjających dużej ich skuteczności.

\section{Wnioski / Conclusions}

1. W badanych gospodarstwach stwierdzono ogółem 32 gatunki roślin towarzyszących uprawom. Skład gatunkowy zbiorowisk chwastów różnił się w zależności od wielkości gospodarstwa oraz rośliny uprawnej. Najbardziej zachwaszczone były łany pszenicy ozimej, natomiast najmniej rzepaku ozimego.

2. Najwięcej chwastów $\mathrm{w}$ łanach roślin uprawnych form ozimych stwierdzono w gospodarstwach największych

Tabela 7. Podstawa wyboru środka ochrony roślin i decyzji o wykonaniu zabiegu

Table 7. The basis for the selection of plant protection product and the decision to perform chemical treatment

\begin{tabular}{|c|c|c|c|c|c|c|}
\hline \multirow{2}{*}{ Wyszczególnienie - Specification } & \multicolumn{5}{|c|}{$\begin{array}{l}\text { Grupa obszarowa gospodarstw } \\
\text { Area groups of farms }\end{array}$} & \multirow{2}{*}{$\begin{array}{l}\text { Średnio } \\
\text { Mean }\end{array}$} \\
\hline & I & II & III & IV & $\mathrm{V}$ & \\
\hline \multicolumn{7}{|c|}{ Podstawa wyboru środka ochrony roślin - The basis for selection of pesticide [\%] } \\
\hline Skuteczność działania - Effectiveness & 10 & 60 & 55 & 65 & 60 & 52 \\
\hline Cena - Price & 90 & 40 & 45 & 25 & 30 & 46 \\
\hline Próg szkodliwości - Harmfulness threshold & 0 & 0 & 0 & 10 & 10 & 2 \\
\hline \multicolumn{7}{|c|}{ Podstawa decyzji - Basis for a decision [\%] } \\
\hline Obserwacje własne - Own observations & 100 & 100 & 85 & 80 & 70 & 87 \\
\hline Profesjonalne doradztwo służb - Professional consulting services & 0 & 70 & 15 & 20 & 30 & 27 \\
\hline Skuteczność zabiegu-Effectiveness of the treatment & 90 & 95 & 92 & 96 & 95 & 94 \\
\hline
\end{tabular}

Źródło: opracowanie własne - Source: own elaboration 
obszarowo (powyżej 100 ha UR), natomiast najmniej w gospodarstwach do 20 ha użytków rolnych.

3. Ocena różnorodności biologicznej flory segetalnej za pomocą wskaźników różnorodności Shannona-Wienera i dominacji Simpsona nie wykazała znacznych różnic pomiędzy poszczególnymi grupami gospodarstw. Zbliżone wartości wskaźników zbiorowisk chwastów są wynikiem stosunkowo dużej różnorodności gatunkowej we wszystkich grupach gospodarstw.

4. Najliczniej występującymi gatunkami chwastów niezależnie od gatunku rośliny uprawnej były: Ch. album,
V. arvensis, E. crus-galli, A. arvensis, A. spica-venti oraz S. media.

Praca wykonana w ramach realizacji zadania 2.3 Programu Wieloletniego IUNG - PIB w Puławach pt. „Wspieranie działań w zakresie ochrony i racjonalnego wykorzystania rolniczej przestrzeni produkcyjnej w Polsce oraz kształtowania jakości surowców roślinnych na lata 2016-2020".

\section{Literatura / References}

Adamiak E. 2007. Struktura zachwaszczenia i produktywność wybranych agrocenoz zbóż ozimych i jarych w zależności od systemu następstwa roślin i ochrony łanu. Rozprawy i Monografie 129, Uniwersytet Warmińsko-Mazurski, Olsztyn, 146 ss.

Domaradzki K., Kieloch R., Rola H. 2003. Skuteczność herbicydów w zależności od dawki i fazy rozwojowej chwastów. [The effectiveness of herbicides in correlation to dose and growth stage of weeds]. Progress in Plant Protection/Postępy w Ochronie Roślin 43 (1): $109-114$

Feledyn-Szewczyk B. 2012. Ocena różnorodności zbiorowisk segetalnych w roślinach uprawianych w wybranych gospodarstwach ekologicznych w województwie lubelskim. [The assessment of the diversity of weed flora communities in crops cultivated in selected organic farms in Lublin province]. Journal of Research and Applications in Agricultural Engineering 57 (3): 63-72.

Feledyn-Szewczyk B., Duer I. 2007. Zachwaszczenie pszenicy jarej uprawianej w ekologicznym systemie produkcji w porównaniu z innymi systemami produkcji rolnej. [Weed infestation in spring wheat cultivated in organic crop production system in comparison with other crop production systems]. Journal of Research and Applications in Agricultural Engineering 52 (3): 40-44.

Gołębiowska H. 2007. Chwasty - źródła zachwaszczenia, zbiorowiska, szkodliwość, metody ograniczania zachwaszczenia. W: „Integrowana produkcja roślinna. Zagadnienia wybrane" (J. Podleśny, red.). Instytut Uprawy Nawożenia i Gleboznawstwa, Puławy, 212 ss.

Janczak-Tobaszewska D., Tyburski J. 1999. Zachwaszczenie pszenicy jarej i ziemniaków w gospodarstwach ekologicznych i konwencjonalnych. W: „Porównanie ekologicznych i konwencjonalnych gospodarstw rolnych w Polsce” (M. Górny, red.). Szkoła Główna Gospodarstwa Wiejskiego, Warszawa, 54 ss.

Kapeluszny J., Haliniarz M. 2010. Niektóre gatunki ruderalne zadomowione w uprawach na terenie województwa lubelskiego. [Some ruderal weeds settled in the crops in the Lublin region]. Fragmenta Agronomica 27 (2): 70-78.

Kwiatkowski C. 2009. Struktura zachwaszczenia i produkcyjność biomasy pszenicy ozimej oraz chwastów w zależności od systemu następstwa roślin i sposobu pielęgnacji. [Weed infestation structure and biomass productivity of winter wheat and weeds depending on crop sequence system and protection method]. Annales Universitatis Mariae Curie-Skłodowska, Sectio E, Agricultura 64 (3): 69-78.

Orzech K., Rychcik B., Stępień A. 2011. Wpływ sposobów uprawy roli na zachwaszczenie i plonowanie jęczmienia jarego. [The influence of tillage systems on weed infestation and yield of spring barley]. Fragmenta Agronomica 28 (2): 63-70.

Rola H. 2002. Ekologiczne i produkcyjne aspekty ochrony roślin przed chwastami. Pamiętnik Puławski 130 (2): 635-645.

Rola H., Rola J. 2002. Progi szkodliwości chwastów w programach decyzyjnych ochrony roślin zbożowych. [Thresholds for weeds in decision support system programs in plant protection]. Progress in Plant Protection/Postępy w Ochronie Roślin 42 (1): $332-339$.

Stupnicka-Rodzynkiewicz E., Stępnik K., Dąbkowska T., Łabza T. 2004. Różnorodność zbiorowisk chwastów w uprawach zbóż w Beskidach. [Diversity of cereal crops weed communities in the Beskidy mountains]. Fragmenta Agronomica 4 (84): 45-53.

Wesołowski M., Kwiatkowski C., Harasim E. 2005. Wpływ zmniejszonych dawek niektórych herbicydów na plonowanie i zachwaszczenie pszenicy ozimej. [The influence of reduced dose of some herbicides on yielding and weed infestation of winter wheat]. Progress in Plant Protection/Postepy w Ochronie Roślin 45 (2): 1194-1196.

Woźnica Z. 2008. Herbologia. Podstawy biologii, ekologii i zwalczania chwastów. PWRiL, Poznań, 432 ss.

Zanin G., Mosca G., Catizone P. 1992. A profile of the potential flora in maize fields of the Po val-ley. Weed Research 32 (5): $407-418$. DOI: 10.1111/j.1365-3180.1992.tb01902.x.

Ziętara W., Zieliński M. 2016. Polskie gospodarstwa roślinne na tle gospodarstw wybranych krajów. [Polish crop farms at the background of farms from selected countries]. Zagadnienia Ekonomiki Rolnej 2 (347): 73-95. 